\title{
Two Iron-Age Settlement Sites in Germany: From Field Work via Numerical Modeling towards an Improved Interpretation
}

\author{
Georg Kaufmann1* ${ }^{*}$, Burkart Ullrich2, Philipp Hoelzmann ${ }^{3}$ \\ ${ }^{1}$ Institute of Geological Sciences, Geophysics Section, Freie Universität Berlin, Berlin, Germany \\ ${ }^{2}$ Eastern Atlas Geophysical Prospection, Berlin, Germany \\ ${ }^{3}$ Institute of Geographical Sciences, Physical Geography, Freie Universität Berlin, Berlin, Germany \\ Email: ${ }^{*}$ georg.kaufmann@fu-berlin.de
}

Received 20 October 2014; revised 20 November 2014; accepted 15 December 2014

Academic Editor: Hugo G. Nami, Departamento de Ciencias Geológicas (University of Buenos Aires), National Council of Scientific and Technical Research (CONICET), Argentina

Copyright (C) 2015 by authors and Scientific Research Publishing Inc.

This work is licensed under the Creative Commons Attribution International License (CC BY).

http://creativecommons.org/licenses/by/4.0/

(c) (i) Open Access

\section{Abstract}

Geophysical exploration of archaeological sites has been a successful tool becoming more and more popular in the last decades. Many archaeological features can be detected with magnetic gradiometry (MGR), such as fire places, burned loam, metal artifacts, or other remnants, which produce a remanent magnetic signal detectable on the surface. However, as magnetic minerals are also present in natural settings, e.g. sedimentary and magmatic rocks and sediments derived from these host rocks, the MGR signal from archaeological artifacts is often embedded in a broader geomorphological signal, which makes separation of the different sources difficult. We provide geophysical data from two complex archaeological sites in northern Germany, which have been obtained with different methods, e.g. magnetic gradiometry (MGR), electrical resistivity tomography (ERT), electro-magnetic mapping (EM), and ground-penetrating radar (GPR). The combination of geophysical methods maps different material properties of both the geomorphological and the archaeological sources. We then use the three-dimensional modeling tool PREDICTOR to analyze the sources for the geophysical signals, e.g. the dominant signal in Leimbach, resulting from infill of palaeo-channels in the settlement area, and fire places as well as shafts in the hill fort of Lossow. The model prediction enables us to quantify the structures in the sub-surface and therefore helps to unravel complex situations often present in archaeological excavations.

\section{Keywords}

Multi-Geophysical Prospection, Magnetic Gradiometry, Archaeo-Geophysics, Modelling, Field Work

\footnotetext{
${ }^{*}$ Corresponding author.
}

How to cite this paper: Kaufmann, G., Ullrich, B., \& Hoelzmann, P. (2015). Two Iron-Age Settlement Sites in Germany: From Field Work via Numerical Modeling towards an Improved Interpretation. Archaeological Discovery, 3, 1-14. 


\section{Introduction}

Geophysical prospection has improved the search for archaeological structures significantly over the last decades. Nowadays, a magnetic gradiometry (MGR) campaign is almost a standard application before starting an excavation. The reason for the success of geophysical surveys is the difference in material properties between the archaeological target and the surrounding material.

As an example, loam contains iron oxides such as magnetite $\left(\mathrm{Fe}_{3} \mathrm{O}_{4}\right)$, hematite $\left(\alpha-\mathrm{Fe}_{2} \mathrm{O}_{3}\right)$ and goethite $(\alpha-$ $\mathrm{Fe}^{3+} \mathrm{O}(\mathrm{OH})$ ) as well as carbonates such as siderite $\left(\mathrm{Fe}^{2}\left[\mathrm{CO}_{3}\right]\right)$. Here, the magnetite is a strong ferri-magnetic material, which originates either from oxidation of iron $\left(\mathrm{Fe}^{2+}\right)$ (Oldfield, 1992) or from magnetotactic bacteria (Fassbinder et al., 1990; Fassbinder, 2007), and therefore can be detected with MGR surveys. The iron oxides and carbonates, when heated, can chemically react to form maghemite $\left(\gamma-\mathrm{Fe}_{2} \mathrm{O}_{3}\right)$, e.g. from oxidation of magnetite, from heating of siderite, or from heating in the presence of organic material from goethite. Thus, burning loam for the creation of bricks can also create a material with a strong magnetic signal. But also the use of a location as fire site can cause the alteration to maghemite.

Thus, MGR prospection of the sub-soil on sites potentially interesting to archaeology can result in strong signals caused by either the natural occurrence of magnetic material (e.g. magnetite) or by anthropogenic alteration of material (e.g. maghemite, Aspinall et al., 2008). In addition, the contamination of the site by modern iron artifacts such as scrap metal from agricultural activity or shells from ammunition are often also a very strong source of magnetism.

In geophysical surveys, all of the aforementioned signals add up to a complex magnetic gradient map, in which geomorphological, archaeological, and recent sources need to be separated. This task is in most cases not easy to achieve, and archaeologists often excavate all locations with significant MGR anomalies. Here, geophysical exploration can help to unravel the causes of sub-surface anomalies by applying other methods beyond MGR, e.g. electrical resistivity tomography (ERT), electro-magnetic methods (EM), gravimetry (GRAV), or ground- penetrating radar (GPR), which can help deciphering structures in the sub-surface.

In this paper, we present modeling of sub-surface structures for two Iron-Age settlement sites in Germany. The site Leimbach is located along the southern fringes of the Harz Mountains, used by settlers from the Przeworsk culture, who migrated into a location already occupied by the Latène culture. The site Lossow on the banks of the river Oder close to Frankurt/Oder has been a fortified central site with a complex settlement history. Both sites have been investigated intensively with multi-geophysical surveys (Ullrich, 2010; Ullrich et al., 2011; Freibothe et al., 2011; Ullrich et al., 2013), based on gradiometer magnetics, electrical resistivity tomography, georadar, and transient electro-magnetics. The results of these surveys are summarized and then used for a predictive model of the sub-surface features dominating the geophysical responses of the localities.

We start discussing both localities and the multi-geophysical signatures found. Then we introduce our modeling software PREDICTOR used to describe the surface of the localities and to model the sub-surface in terms of the material properties density, magnetisation, porosity, water content, to name a few. We then discuss the model results for the two chosen locations. We finally summarize our key findings and present a short outlook.

\section{Sites}

In this section, we introduce two archaeological sites with complex remnants from the Iron-Age, which have been surveyed with several geophysical methods to achieve a comprehensive picture of the structures in the sub-surface. The sites, Leimbach along the southern slopes of the Harz Mountains in Germany, and Lossow on the left bank of the river Oder in Northern Germany, are shown on the topographical map in Figure 1(a).

Geophysical surveys on both sites aimed to reveal sub-surface structures with different methods. Magnetic gradiometry (MGR) has been carried out with a wheel-based cart system, comprising of 10 fluxgate sensors, a distance wheel and a GPS antenna for geo-referencing (Keller, 2010; Ullrich et al., 2011). Electrical resistivity tomography (ERT) has been used with a multi-electrode system to investigate both depth sections and small areas (Ullrich et al., 2011). Ground-penetrating radar (GPR) with different antennas (200, $500 \mathrm{MHz}$ ) has probed different depth sections of the sub-surface. Both sites have been investigated with a pulse-induction metal detector (EM) to identify ferrous objects in the sub-surface (Freibothe, 2011; Freibothe et al., 2011).

Additionally, drilling cores have been sampled along a transect in Leimbach, with one core recovery and subsequent analysis of the core in terms of magnetic susceptibility, organic and inorganic carbon, $\mathrm{pH}$ and electrical conductivity, as well as mineral detection by X-ray diffractometer analysis. On the prospected surfaces of the 

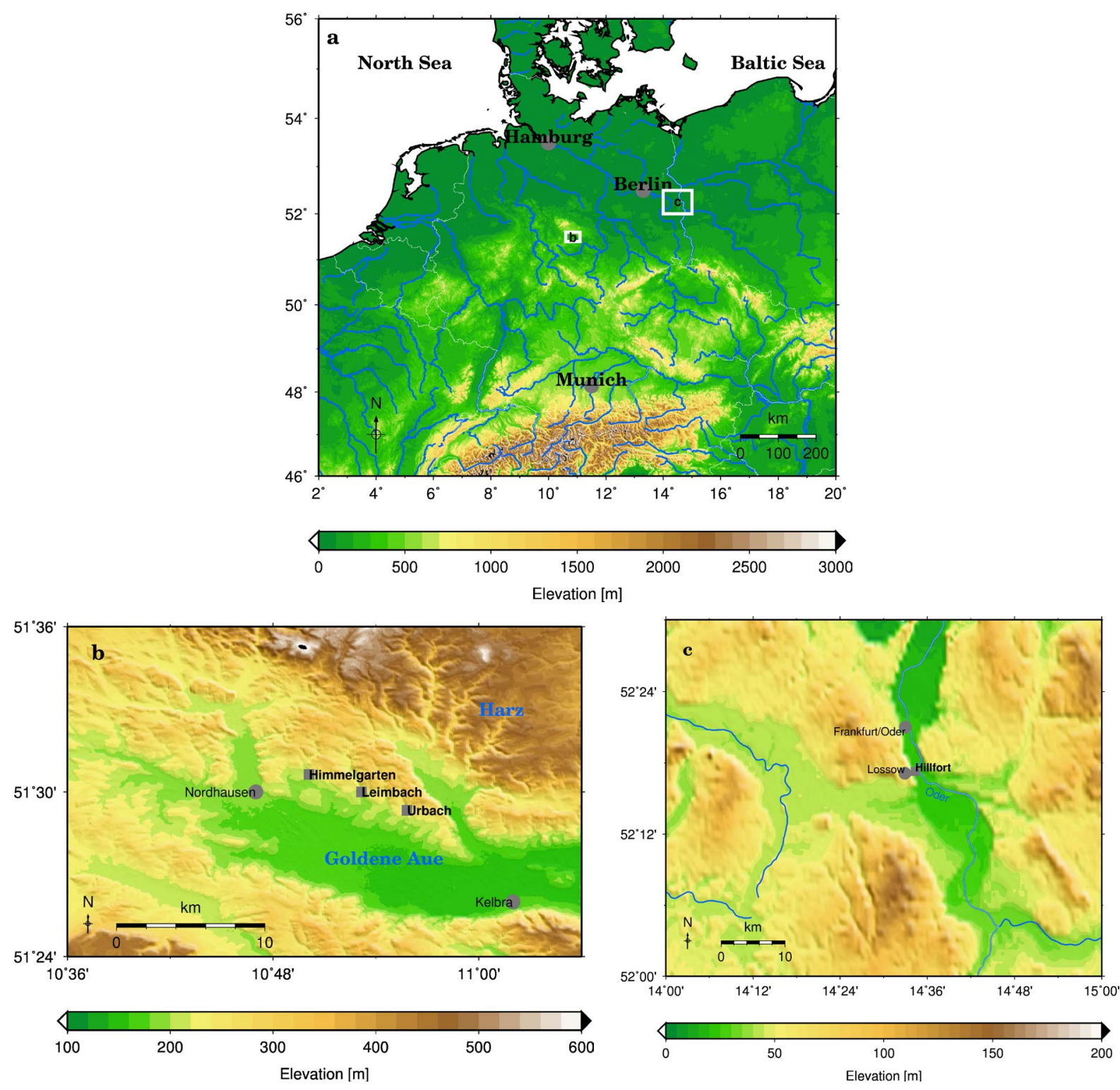

Figure 1. Topographical maps of working areas. (a) Map of Germany with the two locations Lossow (c) and Leimbach (b) marked as white rectangles; (b) Map of the south Harz, with the south Harz Mountains to the north and the fertile Goldene Aue in the south. The three archaeological excavations Himmelgarten, Leimbach, and Urbach are marked as grey rectangles; (c) Map of Lossow, with the river Oder as the border between Poland and Germany. The area of the hillfort is marked as grey rectangle.

archaeological sites, several anomalies were identified by geophysical prospection. Across selected anomalies, typically circular features that can be detected below the plough horizon also by their darker color, samples were taken along a surface transect and analyzed for the magnetic mass susceptibility, organic and inorganic carbon contents; pH value and electric conductivity as well as grain-size analyses (Hoelzmann et al., 2012).

\subsection{Leimbach}

The site Leimbach (Figure 2) is one of several similar archaeological sites located on the northern periphery of the Latène culture, an Iron-Age epoch between 500 and 0 B.C. Here, migrants from the Przeworsk culture appeared around the second century BC (Meyer, 2005).

The site, one of several localities with settlement structures from both the Latène and Przeworsk cultures, lies 


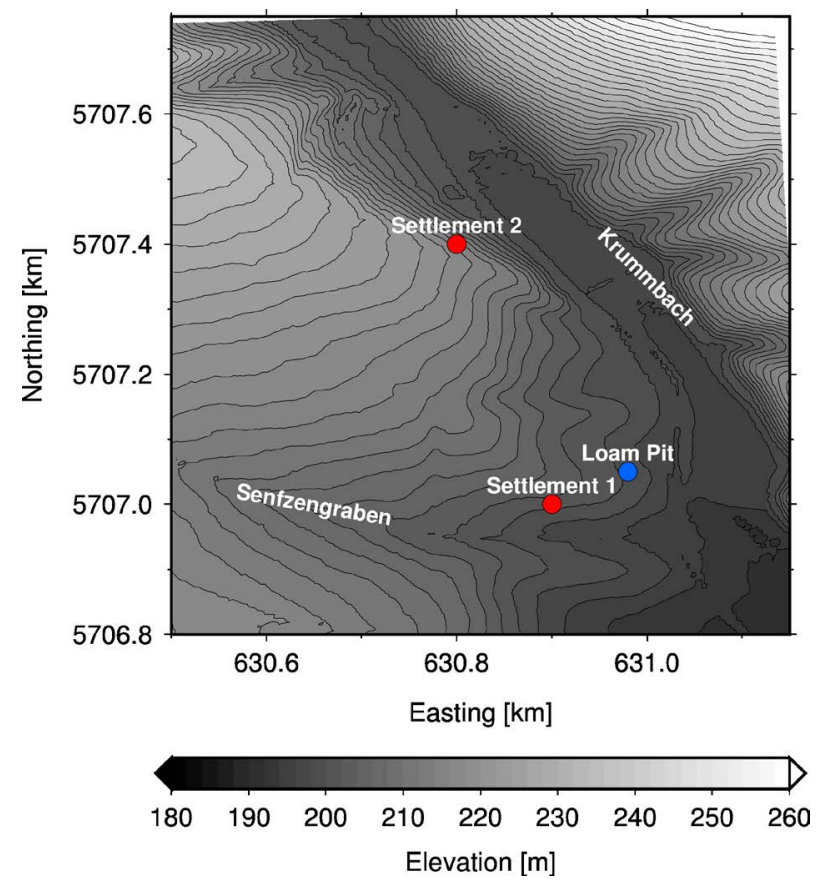

Figure 2. Site Leimbach. Topography is derived from a DEM and contoured, specific sites are indicated by colored dots.

between the rugged Harz Mountains in the north and the fertile plain Goldene Aue in the south (Figure 1(b)). The Harz Mountains, a mountain chain stretching around $110 \mathrm{~km}$ in northwest-southeast direction and rising to $1141 \mathrm{~m}$ at its highest location, the Brocken, comprises Palaeozoic and Mesozoic rocks, from which copper and silver ores have been mined since the early Middle Ages. The iron ores resulted in the human settlement of the region, with local iron production from bog-ore deposits and iron-rich layers in the Buntsandstein formation that were exploited since the early Iron Age.

The Iron-Age settlement of Leimbach lies underneath a large field west of the small river Krummbach, which is dammed by an earthen dam at the site and the creek Senfzengraben to the south (Figure 3(a)). The area is characterized by sandstones from the Buntsandstein formation, covered by a complex soil sequence of varying thickness between 0.5 to 1.5 meter, consisting of eluvial, illuvial, colluvial and parent soil horizons on top of the sandstone bedrock.

The area has been mapped extensively with several geophysical methods, and results are described in detail (see Ullrich et al., 2011; Freibothe, 2011; Freibothe et al., 2011). Here we will only summarize the key findings characteristic for the site.

The MGR results shown in Figure 3(b) reveal several large coherent structures stretching in a west-east direction, which are characterized by a positive anomaly with a negative fringe along the northern parts. These anomalies, that today often form dry valleys, have been suggested to be palaeo-channels that were incised into the bedrock and incised further under peri-glacial conditions during the late Glacial when the subsoil was sealed by permafrost which prevented water from percolating and allowed dissection. During peri-glacial conditions, loess sedimentation occurred and the palaeo-channels were subsequently filled with sediments. During the settlement phase of the Przeworsk culture the infilling of the channels accelerated and up to $2 \mathrm{~m}$ of colluvial sediments accumulated in these depressions. This strong geomorphological signal masks smaller-scale MGR signals from other sources. In the south close to the river Krummbach, an area of large-amplitude (larger than $10 \mathrm{nT}$ ) scattered anomalies marks the area of a small pit, from which material for the earthen dam has been taken during its construction by medieval monks from a nearby monastery. Finally, two areas with positive vertical dipole anomalies of up to $1 \mathrm{nT}$ amplitude, one in the south close to the Senfzengraben creek, one along the northern edge of the surveyed area, indicate pits from the Iron Age settlements.

The EM results obtained along the southern section of the site are very similar to the MGR results (Figure 3(b)): The pit is clearly visible with amplitudes up to $20 \mathrm{mV}$, and numerous scattered anomalies are present and 


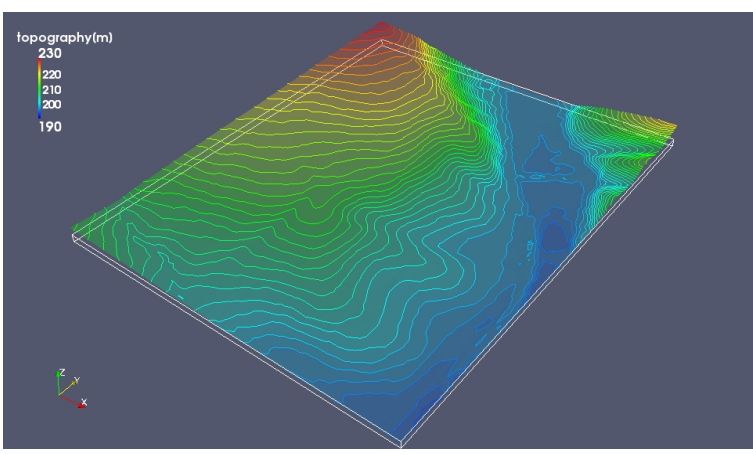

(a)

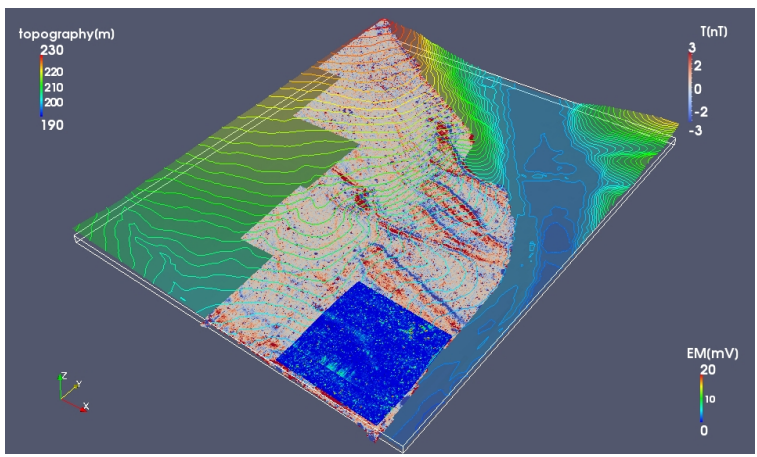

(c)

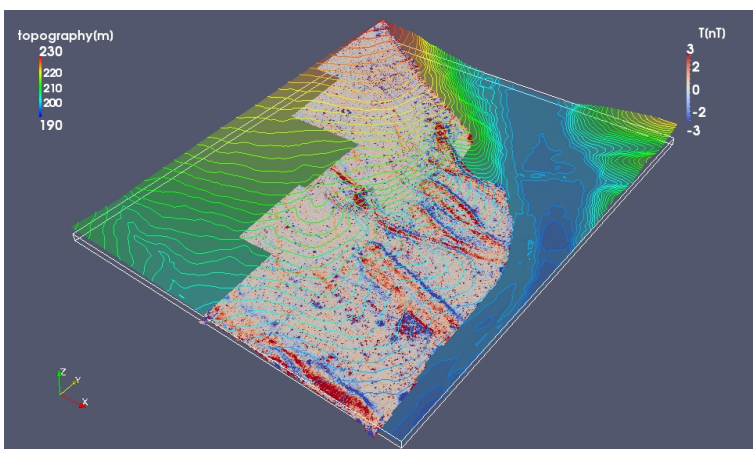

(b)

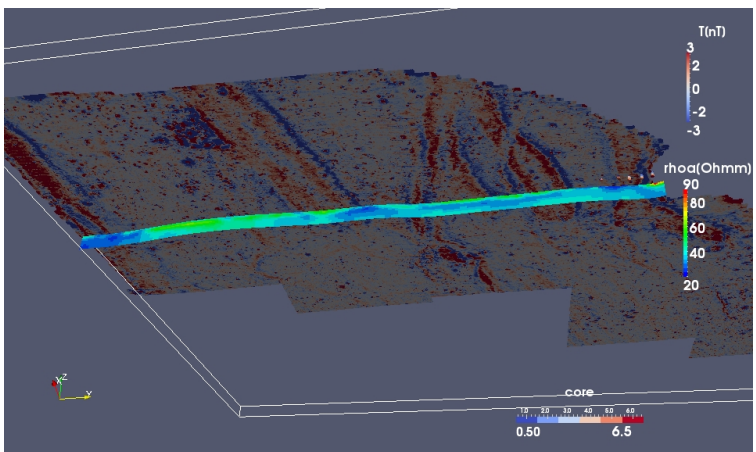

(d)

Figure 3. Site Leimbach. North is in the positive y-direction. (a) Topography, with the river Krummbach in the east, the creek Senfzengraben in the south (just outside of the model), and the field streching from the creeks towards the north-west; (b) As (a), but magnetic gradiometry (MGR) results superimposed. Scale is on the right side; (c) As (a), but with pulse-detection metal detector (EM) results superimposed. Scale is on the right side; (d) View from below onto the magnetic gradiometry (MGR) and electrical resistivity tomography (ERT) results. Scale is on the right side.

possibly represent modern ferrous artifacts.

The ERT cross section oriented roughly in south-north direction is shown in Figure 3(d). Here, the view is from below the topography, and the electrical resistivities range from 20 to $90 \Omega \mathrm{m}$; the depth range for the cross section is $5 \mathrm{~m}$. While the low resistivities represent water-saturated soft sediments of the soil, the higher resistivities, which correlate to the geomorphological MGR results of the palaeo-channels, might indicate the infill of the channels, which can be partly deprived of water do to its coarser structure.

The northernmost palaeo-channel has been probed with 5 cores, from which one core has been studied in detail (Ißelhorst, 2011). The cores reveal the sub-surface stratigraphy of the bedrock and prove the incision of the palaeo-channels into the bedrock with sandstones from the Buntsandstein formation at the base. Then follows the peri-glacial debris, loess-like sediments as first infill layer, a layer rich in archaeological artifacts (probably from the Przeworsk culture), and colluvial sediments on top (Hoelzmann et al., 2012).

The archaeological layer is characterized by a positive magnetic mass susceptibility resulting from burned loam that creates a magnetic signal. Additionally, this cultural layer exhibits increased total organic carbon (TOC) and decreased total inorganic carbon (TIC) contents. The elevated TOC originates from small charcoal pieces whereas the decreased TIC content is the result of decalcification when this colluvial layer originally formed the top soil layer. The anomalies on the archaeological sites identified by geophysical prospection show similar sequences. Samples were taken across these anomalies starting and ending in the parent soil horizon, which consists of loess-like sediments. The parent soil/loess-like sediments exhibit low TOC but elevated TIC contents together with low magnetic mass susceptibility. The darker anomalies show opposite values: higher TOC but lower TIC contents and higher magnetic mass susceptibility.

\subsection{Lossow}

The site Lossow (Figure 4) is located on the western bank of the river Oder close to the city of Frankfurt/Oder in 


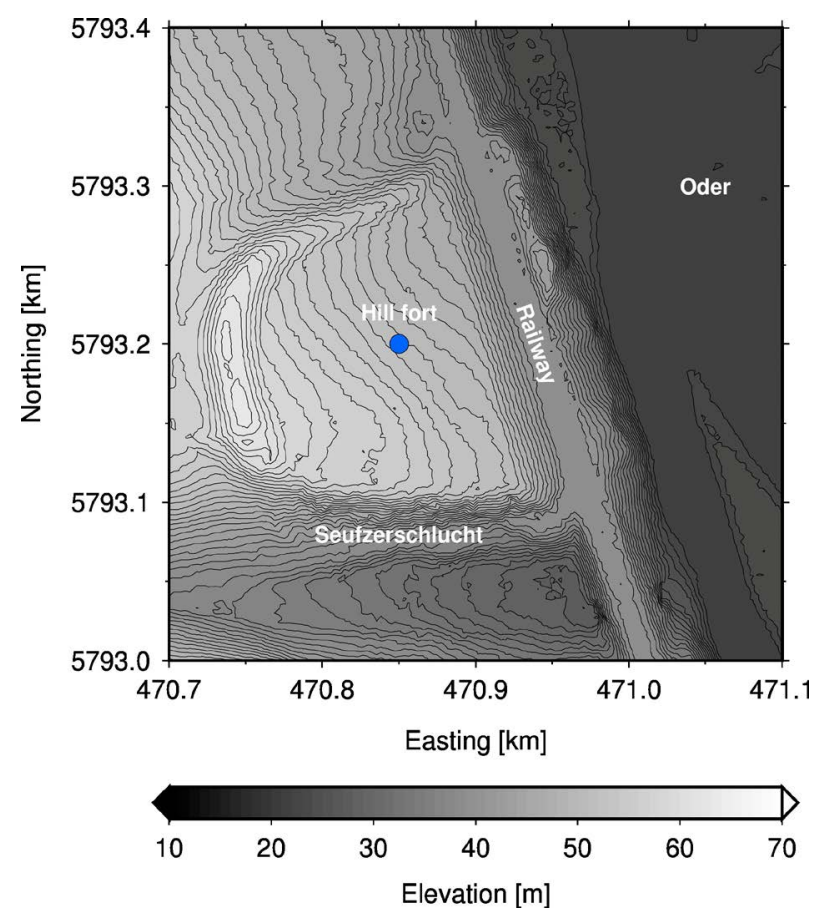

Figure 4. Site Lossow. Topography is derived from a DEM and contoured, specific sites are indicated by colored dots.

northeastern Germany. The Oder, border between Poland and Germany, drains the Polish Basin towards the Baltic Sea. From the river Oder, a $40 \mathrm{~m}$ steep cliff leads to the hill fort site Lossow, which has been constructed as fortified settlement during the Bronce Age (1200 BC), and has been in use throughout the Bronze and Iron Age as central site. The hill fort site has been re-used in the Slavic period (800 - $1000 \mathrm{AD}$ ). Archaeological investigations started early (e.g. Agahd, 1911) and continues today (Beilke-Voigt, 2010). The area is covered with sand and till deposits of Late Pleistocene age. The hill fort itself is an enclosed area about $240 \times 200 \mathrm{~m}$ in size, and delimited to the north and west by a $4-6 \mathrm{~m}$ high artificial wall made up of wooden posts and stones (Beilke-Voigt, 2010); in the south, the steep valley Seufzerschlucht provides a natural border (Figure 5(a)). During railway construction along the river Oder, several shafts were found on the site (e.g. Unverzagt, 1930; Griesa, 1989). These shafts, about a meter below ground, $1 \mathrm{~m}$ in diameter and 5-6 $\mathrm{m}$ deep, are thought to be offering sites, with remains of human and animal bones found in them.

The area has been mapped extensively with several geophysical methods, and results are described in detail in Ullrich (2010) and Ullrich et al. (2013). Here we will only summarize the key findings characteristic for the site.

The MGR results inside the hill fort reveal a complicated picture of different anomalies (Figure 5(b)). There are numerous large-amplitude signals of several $100 \mathrm{nT}$, which are related to modern artifacts either from farming or the second world war. Clearly visible in the cluttered MGR map are positive dipolar structures of up to 10 nT with small negative fringes, which result from sources close to the surface, e.g. Slavic fireplaces. In these cases, an un-damped near-vertical dipole signal is present. The other group of dipolar structures shows only positive anomalies below $5 \mathrm{nT}$ and no significant negative fringe, indicating sources buried deeper in the ground. This group of signals is probably related to the infill of the artificial shafts.

The EM results obtained inside the hill fort corroborate the complicated sources in the sub-surface of the site (Figure 5(c)). Numerous positive anomalies up to several tens mV identify either iron sources from modern relicts or burned material close to the surface from the Slavic period.

The GPR signal (Figure 5(d)) has been obtained with a $500 \mathrm{MHz}$ antenna. The slice shown is for two-way travel times of 6 - $8 \mathrm{~ns}$, corresponding to less than $1 \mathrm{~m}$ in depth. The signal shows a strong difference in amplitude between the western and eastern portion, which is simply the result of two different survey days with varying weather conditions. In the south, a linear reflection reveals an old agricultural path, hidden today. In the south-eastern corner, the circular structure is related to a Slavic fortification wall. 


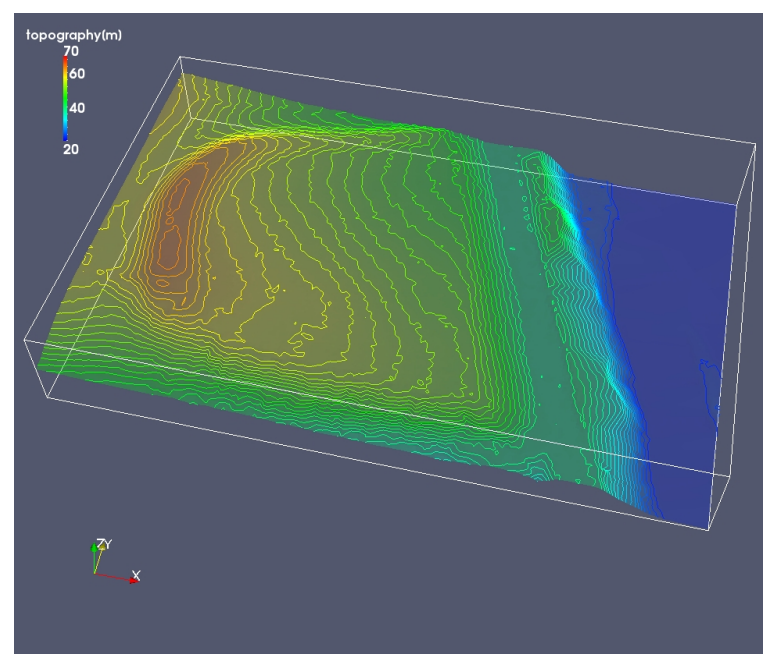

(a)

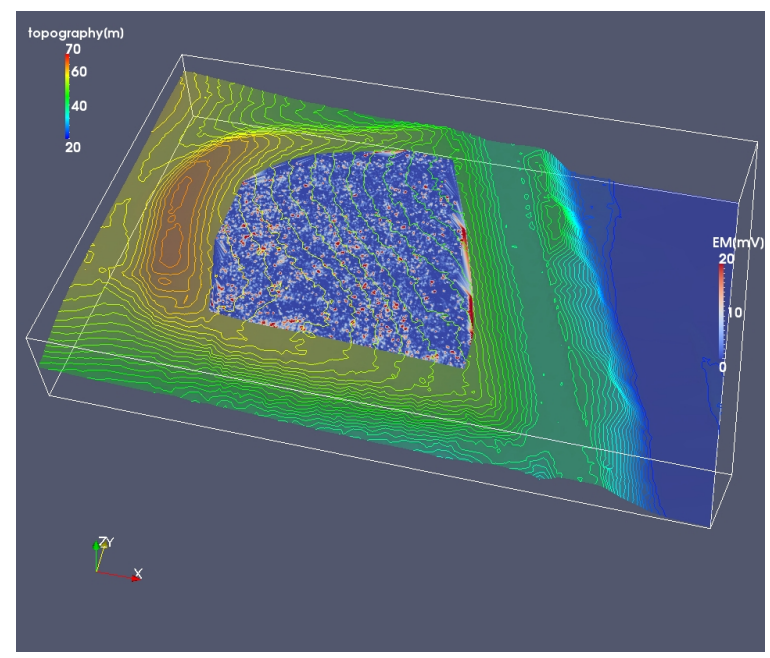

(c)

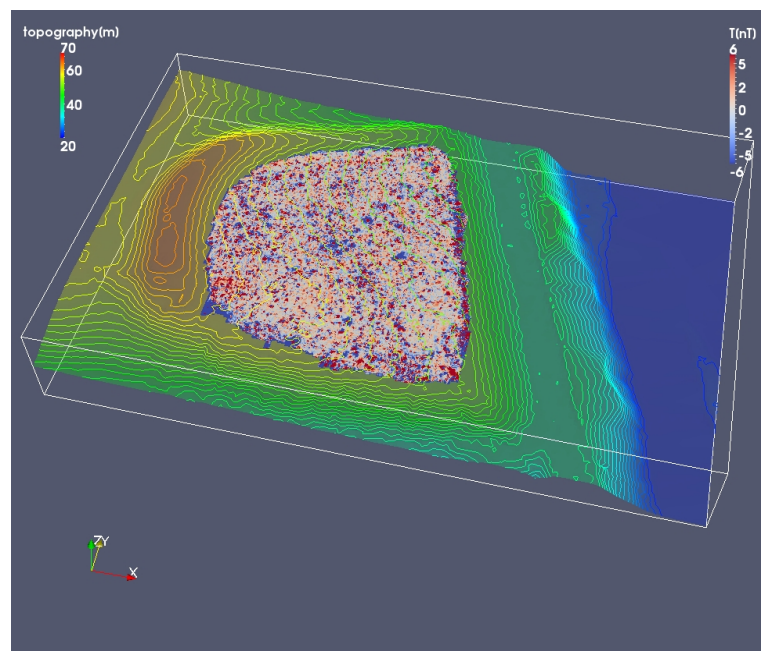

(b)

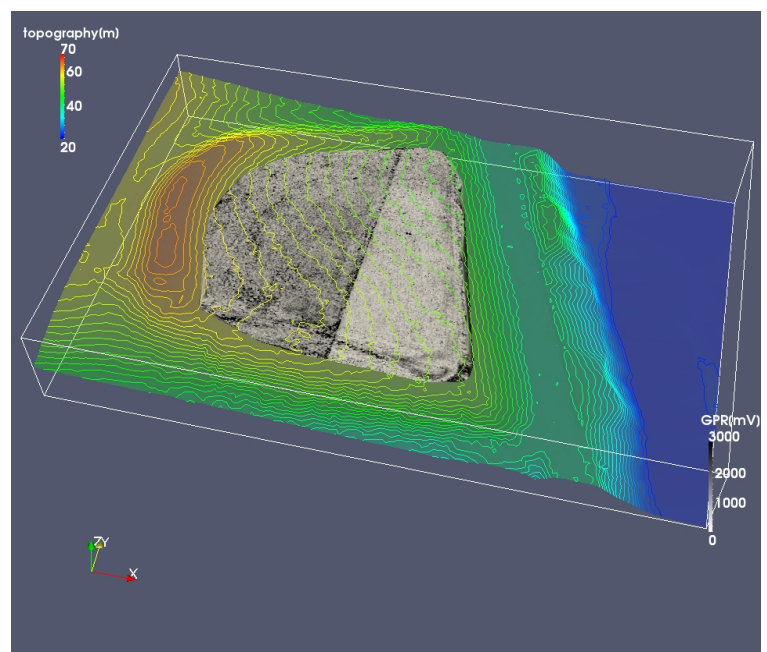

(d)

Figure 5. Site Lossow. North is in the positive y-direction. (a) Topography, with the river Oder in the east and the hillfort encircling the area seen as topographic barrier; (b) As (a), but magnetic gradiometry (MGR) results superimposed. Scale is on the right side; (c) As (a), but with pulse-detection metal detector (EM) results superimposed. Scale is on the right side; (d) As (a), but with georadar (GPR) results superimposed. Scale is on the right side.

\section{Model}

In this section, we introduce the numerical model used to identify and characterize the sub-surface structure of the two sites by means of geophysical modeling. The software package PREDICTOR developed by Georg Kaufmann is based on a digital topographical model of the region of interest, extended in to the depth with several different lithological layers. The numerical model consists of three parts, the assemblage of the model, the solution of the governing equations for water flow and heat transfer, and the prediction of geophysical signals.

\subsection{Assemblage}

The model domain is characterized by its extent, with coordinates $x(i), i=1, n x[\mathrm{~m}]$ in the northern direction, $y(j)$, $j=1, n y[\mathrm{~m}]$ in the eastern direction, $z(k), k=1, n z[\mathrm{~m}]$ as elevation. The counters $n x, n y$, and $n z$ provide the discretisation of the model domain. With a given topography topo $(i, j)[\mathrm{m}]$, the program adds $n z-1$ depth layers below the surface. Each layer consists of $(n x-1) \times(n y-1)$ elements, and each element is represented by material properties (see Table 1). Once the model domain is assembled, boundary conditions for the different tasks 
Table 1. Material properties for the PREDICTOR tool.

\begin{tabular}{|c|c|c|c|}
\hline Variable & & Unit & Name \\
\hline$\Phi$ & & {$[-]$} & Porosity \\
\hline$\Theta$ & & {$[-]$} & Water content \\
\hline$\rho_{\text {bulk }}$ & & {$\left[\mathrm{kg} / \mathrm{m}^{3}\right]$} & Bulk density \\
\hline$\rho_{\text {air }}$ & & {$\left[\mathrm{kg} / \mathrm{m}^{3}\right]$} & Air density \\
\hline$\rho_{\text {water }}$ & & {$\left[\mathrm{kg} / \mathrm{m}^{3}\right]$} & Water density \\
\hline$\eta$ & & {$[\mathrm{Pa} \cdot \mathrm{s}]$} & Dynamic viscosity \\
\hline$g$ & 9.81 & {$\left[\mathrm{~m} / \mathrm{s}^{2}\right]$} & Gravitational acceleration \\
\hline$G$ & $6.672 \times 10^{-11}$ & {$\left[\mathrm{~m}^{3} / \mathrm{kg} / \mathrm{s}^{2}\right]$} & Gravitational constant \\
\hline$\mu_{0}$ & $4 \times 10^{-7}$ & {$[\mathrm{~V} \cdot \mathrm{s} /(\mathrm{A} \cdot \mathrm{m})]$} & Magnetic permeability \\
\hline$\epsilon_{0}$ & $8.854187817 \times 10^{-12}$ & {$[\mathrm{~A} \cdot \mathrm{s} /(\mathrm{V} \cdot \mathrm{m})]$} & Electrical permeability \\
\hline$B$ & & {$[\mathrm{nT}]$} & Magnetic flux \\
\hline$M$ & & {$[\mathrm{~A} / \mathrm{m}]$} & Magnetization \\
\hline$M_{\text {bulk }}$ & & {$[\mathrm{A} / \mathrm{m}]$} & Bulk magnetization amplitude \\
\hline$I_{m}$ & & {$\left[{ }^{\circ}\right]$} & Magnetic inclination \\
\hline$D_{m}$ & & {$\left[{ }^{\circ}\right]$} & Magnetic declination \\
\hline$T$ & & {$[\mathrm{~K}]$} & Temperature \\
\hline $\boldsymbol{q}_{\mathrm{t}}$ & & {$\left[\mathrm{W} / \mathrm{m}^{2}\right]$} & Thermal heat flow \\
\hline$K_{t}$ & & {$[\mathrm{~W} / \mathrm{m} / \mathrm{K}]$} & Thermal conductivity \\
\hline$\kappa_{t}=\frac{K_{t}}{\rho c_{p}}$ & & {$\left[\mathrm{~m}^{2} / \mathrm{s}\right]$} & Thermal diffusivity \\
\hline$c_{p}$ & & {$[\mathrm{~J} / \mathrm{kg} / \mathrm{K}]$} & Thermal specific heat capacity \\
\hline$H^{*}$ & & {$\left[\mathrm{~W} / \mathrm{m}^{3}\right]$} & Thermal heat production per volume \\
\hline$H=\frac{H^{*}}{\rho}$ & & {$[\mathrm{W} / \mathrm{kg}]$} & Thermal heat production per mass \\
\hline$\alpha_{t}$ & & {$[1 / \mathrm{K}]$} & Thermal expansivity \\
\hline$p$ & & {$[\mathrm{~m}]$} & Pressure head \\
\hline$h=p+z$ & & {$[\mathrm{~m}]$} & Hydraulic head \\
\hline$Q_{h}$ & & {$\left[\mathrm{~m}^{3} / \mathrm{s}\right]$} & Hydraulic flow rate \\
\hline $\boldsymbol{q}_{h}$ & & {$[\mathrm{~m} / \mathrm{s}]$} & Darcy velocity \\
\hline$K_{h}$ & & {$[\mathrm{~m} / \mathrm{s}]$} & Hydraulic conductivity \\
\hline$\kappa_{h}$ & & {$\left[\mathrm{~m}^{2}\right]$} & Hydraulic permeability \\
\hline$S_{h}$ & & {$[1 / \mathrm{m}]$} & Hydraulic specific storage \\
\hline
\end{tabular}

to solve are assigned. For the groundwater part, precipitation and surface temperatures are used to derive the groundwater recharge, accounting for evapo-transpiration. A hydraulic base level is defined as resurgence or river. For the temperature part, the surface temperature needs to be complemented by a basal heat flow.

\subsection{Solution}

In a first step, a groundwater problem is solved for given boundary conditions (head and resurgence as Dirichlet 
boundary condition, precipitation and wells as Neumann boundary condition):

$$
S_{h} \frac{\partial h}{\partial t}=\nabla \cdot\left(K_{h} \nabla h\right),
$$

with $h[\mathrm{~m}]$ hydraulic head, $t[\mathrm{~s}]$ time, $\nabla=(\partial / \partial x, \partial / \partial y, \partial / \partial z)^{\mathrm{T}} \quad[1 / \mathrm{m}]$ Nabla differential operator, $S_{h}[1 / \mathrm{m}]$ hydraulic specific storage, and $K_{h}[\mathrm{~m} / \mathrm{s}]$ hydraulic conductivity. The hydraulic head $h[\mathrm{~m}]$ is the sum of pressure head $p[\mathrm{~m}]$ and elevation head $z[\mathrm{~m}], h=p+z$.

In Equation (1), the diffusion term is defined by the Darcy velocity $\boldsymbol{q}_{h}[\mathrm{~m} / \mathrm{s}]$ :

$$
\boldsymbol{q}_{h}=-K_{h} \nabla h .
$$

The equation is known as Darcy's law for porous laminar flow. The pore velocity $\boldsymbol{v}_{h}[\mathrm{~m} / \mathrm{s}]$ can be derived from the Darcy velocity through

$$
\boldsymbol{v}_{h}=\frac{\boldsymbol{q}_{h}}{\Phi},
$$

with $\Phi[-]$ the porosity, ranging between 0 (no pores) to 1 (void). After solving (1), the resulting hydraulic head $h$ in the model domain is used to derive the height of the water table table $(i, j)$. The water table defines the vadose and phreatic zone in the model domain, and the water content $\Theta$ is assigned for the two regions $(\Theta=1$ for the phreatic zone, $\Theta=0$ for the vadose zone). The water content then defines the infill of the pores in the model, either water- or air-filled.

Based on the results from the hydrological step, the diffusion and advection of heat in the aquifer can be calculated according to

$$
\rho c_{p} \frac{\partial T}{\partial t}=\nabla \cdot\left(K_{t} \nabla T\right)+\rho c_{p} v_{h} \cdot \nabla T+H^{*},
$$

with $T[\mathrm{~K}]$ temperature, $\rho\left[\mathrm{kg} / \mathrm{m}^{3}\right]$ density, $c_{p}[\mathrm{~J} / \mathrm{kg} / \mathrm{K}]$ thermal specific heat, $K_{t}[\mathrm{~W} / \mathrm{m} / \mathrm{K}]$ thermal conductivity, and $H^{*}\left[\mathrm{~W} / \mathrm{m}^{3}\right]$ thermal heat production. In (4), the diffusion term is defined by the thermal heat flow $\boldsymbol{q}_{t}$ $\left[\mathrm{W} / \mathrm{m}^{2}\right]$ :

$$
\boldsymbol{q}_{t}=-K_{t} \nabla T .
$$

The equation is known as Fourier's law for heat conduction.

With the distribution of porosity, water content, and temperature now known, different material properties are now calculated:

Density follows from the definition of the material (bulk density $\rho_{\text {bulk }}\left[\mathrm{kg} / \mathrm{m}^{3}\right]$, porosity $\Phi[-]$, water content [-] temperature $T[\mathrm{~K}])$ :

$$
\rho=\left[\rho_{\text {bulk }}(1-\phi)+\rho_{\text {air }} \phi(1-\Theta)+\rho_{\text {water }} \phi \Theta\right]\left[1-\alpha_{t}\left(T-T_{0}\right)\right],
$$

with $\rho_{\text {bulk, }} \rho_{\text {air, }} \rho_{\text {water }}\left[\mathrm{kg} / \mathrm{m}^{3}\right]$ the densities of bulk, air, and water, respectively, $\alpha_{t}[1 / \mathrm{K}]$ the thermal expansivity, and $T_{0}[\mathrm{~K}]$ the surface temperature.

For magnetisation, we argue that both air- or water-filled pores do not contribute to magnetization (e.g. Fialova et al., 2006; Maier et al., 2006), thus the magnetisation is controlled by the bulk magnetisation:

$$
M=M_{\text {bulk }}(1-\phi),
$$

with $M_{\text {bulk }}[\mathrm{A} / \mathrm{m}]$ magnetisation of the bulk composition.

Electrical resistivity $\varrho_{e}[\Omega \cdot \mathrm{m}]$ is based on Archie's law:

$$
\varrho_{e}=\varrho_{e, \text { bulk }}+\varrho_{e, \text { water }}\left(a_{\text {Archie }} \phi^{-m_{\text {Archie }}} \theta^{-n_{\text {Archie }}}\right) \text {, }
$$

with $\varrho_{e, \text { bulk }}$ and $\varrho_{e \text {,water }}[\Omega \cdot \mathrm{m}]$ the bulk and water electrical resistivity, respectively, $a_{\text {Archie }}[-]$ the Archie tortuosity factor, $m_{\text {Archie }}[-]$ the Archie cementation exponent, $n_{\text {Archie }}[-]$ the Archie saturation exponent.

\subsection{Prediction}

Once the material properties are derived from lithology, distribution of porosity, water content, and temperature, several geophysical signals can be derived. 
For gravity, a reference density $\rho_{\text {ref }}\left[\mathrm{kg} / \mathrm{m}^{3}\right]$ is defined, resembling a typical average for the site modeled. Then the Bouguer gravity $\Delta g_{B}\left[\mathrm{~m} / \mathrm{s}^{2}\right]$ is predicted for surface locations $x_{o b s}$ and $y_{o b s}[\mathrm{~m}]$ and the vertical coordinate $z_{o b s}$ [m] comprising the elevation and a sensor-over-ground offset, following

$$
\Delta g_{B}=G \iiint_{x, y, z} \Delta \rho\left(x^{\prime}, y^{\prime}, z^{\prime}\right) \frac{z_{o b s}-z^{\prime}}{r^{3}} \mathrm{~d} x^{\prime} \mathrm{d} y^{\prime} \mathrm{d} z^{\prime},
$$

with $G\left[\mathrm{~m}^{3} / \mathrm{kg} / \mathrm{s}^{2}\right]$ the gravitational constant, $\Delta \rho=\rho-\rho_{\text {ref }}\left[\mathrm{kg} / \mathrm{m}^{3}\right]$ the density difference between sub-surface point and reference density, $r=\sqrt{\left(x_{o b s}-x^{\prime}\right)^{2}+\left(y_{o b s}-y^{\prime}\right)^{2}+\left(z_{o b s}-z^{\prime}\right)^{2}}$ [m] the distance between surface observation point $\left.x_{o b s}, y_{o b s}, z_{o b s}\right)[\mathrm{m}]$ and sub-surface integration point $\left(x^{\prime}, y^{\prime}, z^{\prime}\right)[\mathrm{m}]$. In practice, the volume integration is replaced by a summation over finite elements.

For magnetics, the magnetic induction $\Delta \boldsymbol{B}[\mathrm{nT}]$ is calculated from a source represented by a dipole approximation in the sub-surface for surface locations $x_{o b s}$ and $y_{o b s}[\mathrm{~m}]$ and the vertical coordinate $z_{o b s}[\mathrm{~m}]$ comprising the elevation and a sensor-over-ground offset. The buried magnetic dipole is characterized by a magnetization $\boldsymbol{M}=M\left(\cos I_{m} \cos D_{m}, \cos I_{m} \sin I_{m}, \sin I_{m}\right)^{\mathrm{T}}$, with $M[\mathrm{~A} / \mathrm{m}]$ the amplitude (see definition above), $I_{m}\left[{ }^{\circ}\right]$ the inclination and $D_{m}\left[{ }^{\circ}\right]$ the declination:

$$
\Delta \boldsymbol{B}\left(x_{o b s}, y_{o b s}, z_{o b s}\right)=\frac{\mu_{0}}{4 \pi} \frac{\frac{4}{3} \pi R^{3} M}{r^{3}}\left[3\left(\hat{M}_{x} \hat{r}_{x}+\hat{M}_{y} \hat{r}_{y}+\hat{M}_{z} \hat{r}_{z}\right) \hat{r}-\hat{m}\right],
$$

with $\mu_{0}$ the magnetic permeability of free space, $R[\mathrm{~m}]$ a fictive radius derived from the discretised element geometry, $r=\sqrt{\left(x_{o b s}-x^{\prime}\right)^{2}+\left(y_{o b s}-y^{\prime}\right)^{2}+\left(z_{o b s}-z^{\prime}\right)^{2}}$ [m] the distance between surface observation point $\left(x_{o b s}\right.$, $\left.y_{o b s}, z_{o b s}\right)[\mathrm{m}]$ and sub-surface integration point $\left(x^{\prime}, y^{\prime}, z^{\prime}\right)[\mathrm{m}]$. The hats indicate unity vectors or components thereof. The MGR signal is derived by calculating the vertical component $B_{z}$ for two different sensor-over-ground offsets.

\section{Results}

In this section, we apply our numerical model PREDICTOR to the MGR data from the two sites Leimbach and Lossow, as both sites are characterized by a complicated MGR signal, with contributions from different sources.

\subsection{Leimbach}

For the Leimbach site south of the Harz Mountains, we have assembled a model from a 5 m digital elevation model and the structural information of the local geology and the information of the local cores taken. In Figure 6(a), a view towards the north-west is shown, with semi-transparent topography and four palaeo-channels below. The northernmost palaeo-channel (light gray), over which the transect with five cores has been carried out, has been constrained to start $40 \mathrm{~cm}$ below ground and to be $2 \mathrm{~m}$ thick. Its extent is guided by the coherent largescale MGR anomaly. The three other palaeo-channels have similar depth extensions and extents also derived from the MGR anomalies.

In Figure 6(b), the MGR response caused by the palaeo-channels as a result from the PREDICTOR model is shown. Both the amplitude and the shape of the MGR signal have been reproduced successfully. The successful match has been achieved with a magnetisation of around $0.1 \mathrm{~A} / \mathrm{m}$, which corresponds to a susceptibility of around $\chi=2.5 \times 10^{-3}$. This value is fairly high, when compared to the measured susceptibility from the core samples. More interestingly, the direction of the magnetisation needs to be horizontal and in opposite direction $\left(I_{m}=0^{\circ}, D_{m}=180^{\circ}\right.$ ), which would correspond to a position of the site in equatorial regions during the time the magnetisation was imprinted. For the Harz Mountains, this was about 300 Myr ago in the Late Carboniferous Period. However, this hypothesis is highly unlikely, as we assume an age of the channel infill of about late Pleistocene to Holocene. Therefore the direction of the magnetisation of the channel infill needs to be interpreted in a different way: As the sediment infill of the palaeo-channels has been transported into the channels from a catchment further upstream, the sediments, including the magnetic minerals, have been rearranged, and the gross direction of all mineral dipoles is now oriented in the observed direction. 


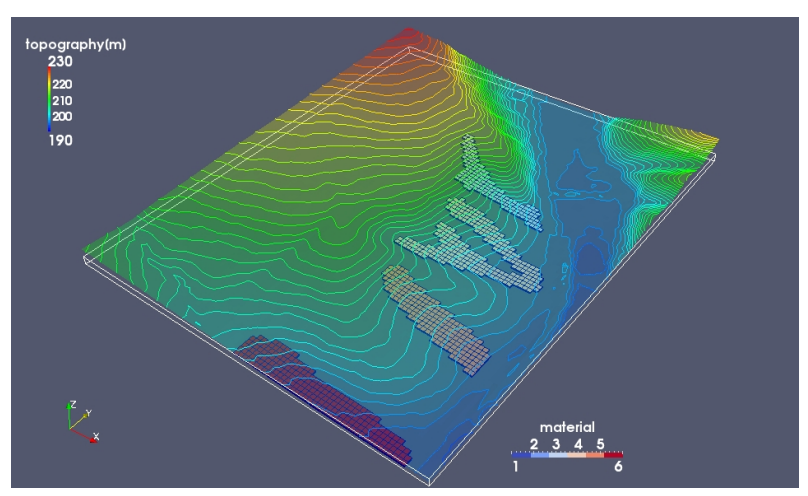

(a)

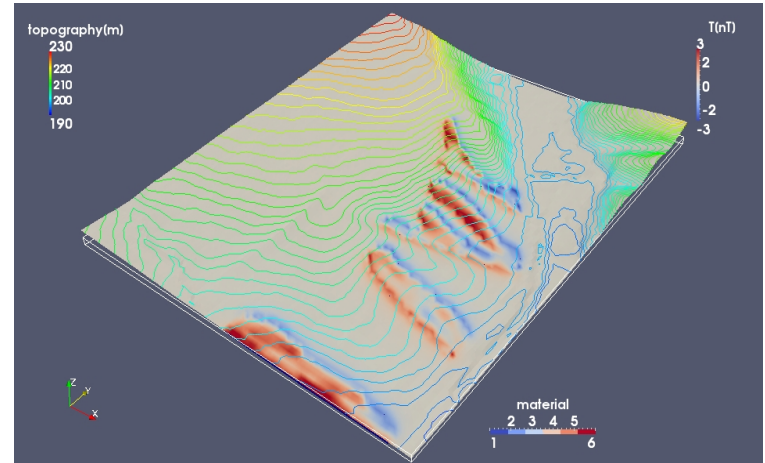

(b)

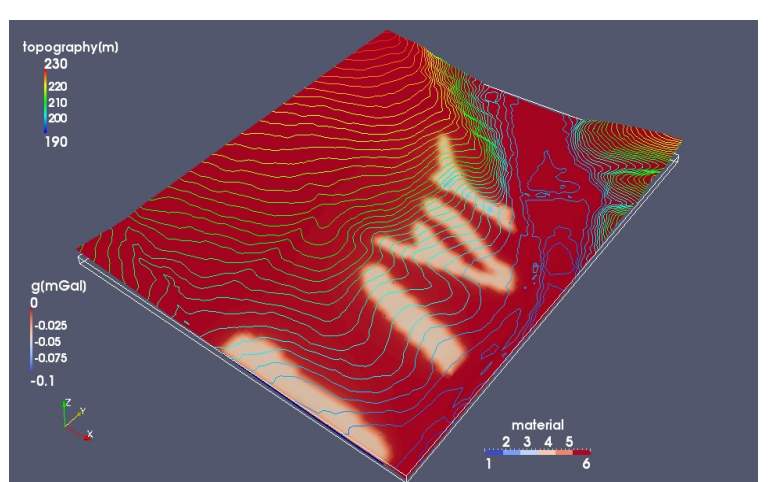

(c)

Figure 6. Site Leimbach. North is in the positive y-direction. (a) Modelled palaeo-channels (for properties see table); (b) Modelled magnetic gradiometry. Scale is on the right side; (c) Modelled gravity. Scale is on the left side.

We have also predicted the Bouguer gravity signal of the peri-glacial infill by assuming a reference density of $\rho_{\text {ref }}=2200 \mathrm{~kg} / \mathrm{m}^{3}$ for the sandstone dominating the region and a sediment infill density of $1500 \mathrm{~kg} / \mathrm{m}^{3}$. The resulting negative Bouguer anomalies are shown in Figure 6(c). The lower-density infill will result in a negative Bouguer-density signal between -0.05 and $-0.1 \mathrm{mGal}$, which is low but still above the detection limit with modern gravimeters.

With the results obtained for the geomorphological features of the palaeo-channels, we can make a volume estimate of the sediment infill deposited in the channels. From north to south, the three channels comprise $5840 \mathrm{~m}^{3}$, $10,600 \mathrm{~m}^{3}, 7600 \mathrm{~m}^{3}$, and $8280 \mathrm{~m}^{3}$ of sediments. Once knowing the catchment area and the age of the sediments, from the volume a surface denudation rate can be estimated.

\subsection{Lossow}

For the Lossow site, the model has been derived from a $2 \mathrm{~m}$ digital elevation model, and the sub-surface has been modeled to a depth of $25 \mathrm{~m}$ below the surface. In Figure 7(a), the surface topography is shown as semitransparent layer, and below two structural elements are visible: On the one hand a sequence of blocks (pale orange) representing Slavic fireplaces, which extend from 0.5 to $1 \mathrm{~m}$ below ground and have a magnetic susceptibility of $\chi=3 \times 10^{-3}$, and on the other hand several columns starting in $1 \mathrm{~m}$ depth and stretching vertically over $5 \mathrm{~m}$, representing shafts with a susceptibility of $\chi=2 \times 10^{-3}$.

In Figure 7(b), the MGR response for these two archaeological structures is shown. Here, the Slavic fireplaces result in a strong and sharp positive magnetic anomaly with a negative fringe around. The fringe is more pronounced towards the north, because the magnetisation of the fireplaces is assumed parallel to the present magnetic field direction, with an inclination of $I=67^{\circ}$ and a declination of $D=0^{\circ}$. The shafts located deeper in the ground produce a weaker magnetic signal, visible in the mainly positive MGR anomalies. Thus, a distinction of the two structures can be made from the MGR signal. Note that we have assumed a gross direction of the magnetic dipoles in the shafts also coinciding with the current magnetic field directions, which we, however, cannot 


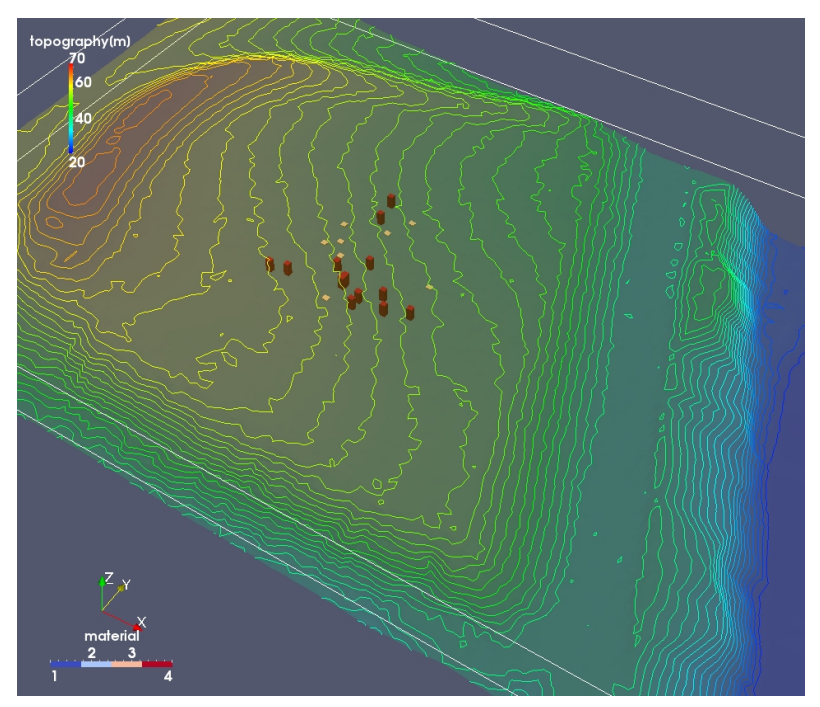

(a)

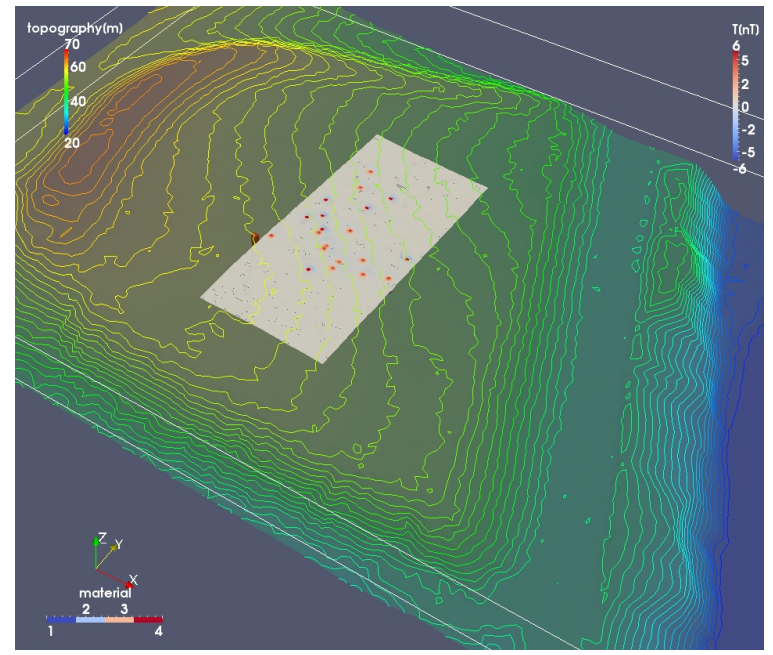

(b)

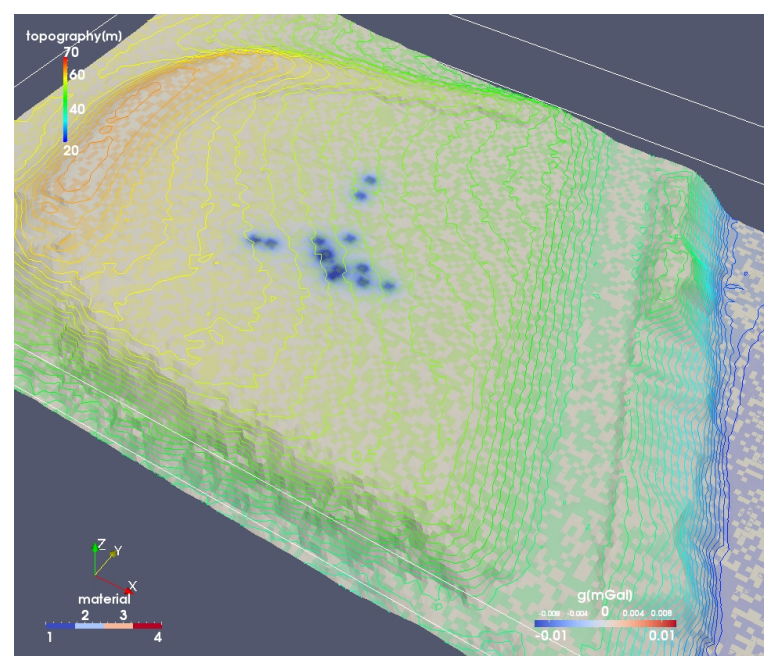

(c)

Figure 7. Site Lossow. North is in the positive y-direction. (a) Modelled Slawic fireplaces (pale orange) and shafts (red); (b) Modelled magnetic gradiometry. Scale is on the right side; (c) Modelled gravity. Scale is on the bottom side.

prove, as the infill of the shafts is likely to produce dipoles in all directions in an arbitrary manner.

The shafts have been dug out and refilled with artifacts and reworked material, thus their density is likely to be smaller than the density of the surrounding soil and rock. When we assume an average density of $\rho=2200$ $\mathrm{kg} / \mathrm{m}^{3}$ for the soil and bedrock, and a lower density of $\rho=1500 \mathrm{~kg} / \mathrm{m}^{3}$ for the shaft infill, a negative Bouguer anomaly will result, as shown in Figure 7 (c). Here, the response of the shafts is with $\Delta g_{B}=-0.05 \mathrm{mGal}$ fairly small, but within the range detectable by modern gravimeters.

\section{Discussion}

We have presented geophysical exploration data for two Iron-Age settlement sites in Germany, that have very different characteristics.

In Leimbach (southern Harz Mountains, Germany), small-scale settlements of the Przeworsk culture migrating into already occupied terrain have been investigated. The Leimbach site has a rich and complicated geophysical signal, with contributions from morphological structures (palaeo-channels) and archaeological remnants (iron smoldering, small-scale ditches), as well as recent structures such as loam pits. The resulting complex signal is visible with several geophysical methods due to material differences in several properties that clearly reflect the 
origin of the material. Our special focus here was a sub-surface model of the palaeo-channels, whose infill dominates the MGR and ERT signals by a broad-scale structure. By combining the geophysical field data, evidence from coring one channel and applying our modeling tool PREDICTOR, we have successfully derived the geometry of the sub-surface palaeo-channels and in so far provide robust data for e.g. the estimation of surface denudation rates and the shape of the terrain surface before colluvial infill affected the palaeo-channels.

In Lossow (Frankfurt/Oder, Germany), an old hill fort has been established in the Iron-Age, and parts are still visible on the surface, e.g. the perimeter wall. Our multi-geophysical exploration has revealed a very complicated locality, with good coherence between MGR and EM results, and additional information obtained from GPR and ERT data for the depth structure. The site is characterized by archaeological remains, especially IronAge shafts probably used for offering, and Slavic fireplaces from a later occupation. Numerous recent artifacts from farming and the world wars complicate the geophysical signals. We have used our geophysical field data and knowledge from archaeological excavations to predict both dominating sub-surface structures, the Slavic fireplace and the Iron-Age shafts. We incorporated the observations into our PREDICTOR program, and we successfully reproduced MGR signals for both features, Slavic fireplaces and Iron-age shafts.

\section{Conclusion}

We have investigated two archaeological sites in Northern Germany with geophysical methods and direct observations. The site Leimbach, an Iron-Age settlement site, is characterized by a complex geophysical signal, present in MGR, ERT and EM results, which results from geomorphological sources (palaeo-channels) and archaeological sources (iron smoldering). The site Lossow, a hill fort, has a complex history, with numerous Ironage shafts in the sub-surface, often covered by Slavic fire places from a later period. Again, the complex features have been mapped by several geophysical methods.

We have used the geophysical results, along with field observations (e.g. drill cores) and information from archaeological excavations to generate a three-dimensional model of the subsurface for each site, identifying the dominant structures. We have derived a three-dimensional model of the sub-surface with our numerical tool PREDICTOR. Our model predictions have been successful in identifying both the palaeo-channels in Leimbach and the shafts in Lossow, and thus the numerical modeling has helped to understand the complex history of the sites.

\section{Acknowledgements}

We would like to thank two anonymous referees, whose comments helped to improve the manuscript. B. Ullrich and P. Hoelzmann acknowledge the support by the German Research Society (DFG) under the excellence cluster 264 (TOPOI: The Formation and Transformation of Space and Knowledge in Ancient Civilizations).

\section{References}

Agahd, R. (1911). Der Burgwall von Lossow bei Frankfurt a. O. Prähist. Zeitschr. 3.

Aspinall, A., Gaffney, C., \& Schmidt, A. (2008). Magnetometry for Archaeologists (Geophysical Methods for Archaeology). Plymouth: Altamira Press.

Beilke-Voigt, I. (2010). Alt bekannt und neu untersucht. In I. Beilke-Voigt, \& F. Schopper (Eds.), Lossow-Alte Forschungen und neue Projekte, Materialien zur Archäologie in Brandenburg, Bd. 4, Lossower Forschungen Bd. 1. Vol. Band 4 (112 p). Rahden/Westfalen.

Fassbinder, J. (2007). Einführung in die Archäometrie. Springer, Ch. Unter Acker und Wadi: Magnetometerprospektion in der Archäologie (pp. 54-75).

Fassbinder, J., Stanjek, H., \& Vali, H. (1990). Occurrence of Magnetic Bacteria in Soil. Nature, 343, 161-163. http://dx.doi.org/10.1038/343161a0

Fialova, H., Maier, G., Petrovsky, E., Kapick, A., Boyko, T., Scholger, R., \& Team, M. (2006). Magnetic Properties of Soils from Sites with Different Geological and Environmental Settings. Journal of Applied Geophysics, 59, 273-283. http://dx.doi.org/10.1016/j.jappgeo.2005.10.006

Freibothe, R. (2011). Archäologische Erkundung mit dem Metalldetektor EMD1: Vergleichende Fallstudien im Rahmen des Topoi-Exzellenz Clusters. Master's Thesis, TU Berlin.

Freibothe, R., Ullrich, B., Beilke-Voigt, I., Kaufmann, G., \& Kirsch, R. (2011). Multigeophysikalische Prospektion am Burgwall Lossow. DGG Mitteilungen, 2, 52-58. 
Griesa, S. (1989). Archäologie in der Deutschen Demokratischen Republik, Denkmale und Funde, Band 2. Ch. Lossow, Ot. von Frankfurt (Oder) (20 p).

Hoelzmann, P., Rauchfuss, B., Ullrich, B., Bebermeier, W., Kaufmann, G., Schütt, B., \& Meyer, M. (2012). Coupling of Geomorphological, Geophysical, Geochemical and Archaeological Spatial Data for a Study of the Interface of the Latène and Przeworsk Cultures in NE Germany. In Bebermeier, Hebenstreit, Kaiser, \& Krause (Eds.), Landscape Archaeology (Vol. 3 of etopoi., pp. 399-403).

Ißelhorst, S. (2011). Sedimentuntersuchungen im Umfeld der archäologischen Grabung “Leimbach”, Nord Thüringen (57p). BSc Thesis, Department of Geosciences, Freie Universität Berlin.

Keller, L. (2010). Geophysikalische Prospektion in der Archäologie Siedlungsgeschichte des Südharzvorlandes. Master’s Thesis, FU Berlin.

Maier, G., Scholger, R., \& Schön, J. (2006). The Influence of Soil Moisture Magnetic Susceptibility Measurements. Journal of Applied Geophysics, 59, 162-175. http://dx.doi.org/10.1016/j.jappgeo.2005.10.001

Meyer, M. (2005). Migration und Adaption-Ein differenziertes Modell zur Erklärung der latènezeitlichen Przeworsk-Funde in Deutschland. In Alt-Thüringen. Jahresschrift des Museums für Ur- und Frühgeschichte Thüringens/des Thüringischen Landesamtes für Archäologische Denkmalpflege bzw. Landesamtes für Archäologie mit Museum für Ur- und Früh-geschichte Thüringens, Band 38.

Oldfield, F. (1992). The Source of Fine-Grained Magnetite in Sediments. Holocene, 2, 180-182.

Ullrich, B. (2010). Erste Ergebnisse geophysikalischer Untersuchungen am Burgwall. In I. Beilke-Voigt, \& F. Schopper (Eds.), Lossow-Alte Forschungen und neue Projekte, Materialien zur Archaölogie in Brandenburg, Bd. 4, Lossower Forschungen Bd. 1. Rahden/Westfalen.

Ullrich, B., Freibothe, R., Zoellner, H., Beilke-Voigt, I., Mehner, A., \& Kaufmann, G. (2013). Multi-Geophysical Prospection in and around the Hillfort Lossow-A Bronze and Iron Age Central Site in Brandenburg, Germany. Arch. Prospection Submitted.

Ullrich, B., Kaufmann, G., Kniess, R., Zoellner, H., Meyer, M., \& Keller, L. (2011). Geophysical Prospection in the Southern Harz Mountains, Germany: Settlement History and Landscape Archeology along the Interface of the Latène and Przeworsk Cultures. Arch. Prospection.

Unverzagt, W. (1930). Neue Ausgrabungen an vor- und frühgeschichtlichen Befestigungen in Nord- und Ostdeutschland. Ch. Der Burgwall von Lossow bei Frankfurt (Oder) (pp. 158-164). 
Scientific Research Publishing (SCIRP) is one of the largest Open Access journal publishers. It is currently publishing more than 200 open access, online, peer-reviewed journals covering a wide range of academic disciplines. SCIRP serves the worldwide academic communities and contributes to the progress and application of science with its publication.

Other selected journals from SCIRP are listed as below. Submit your manuscript to us via either submit@scirp.org or Online Submission Portal.
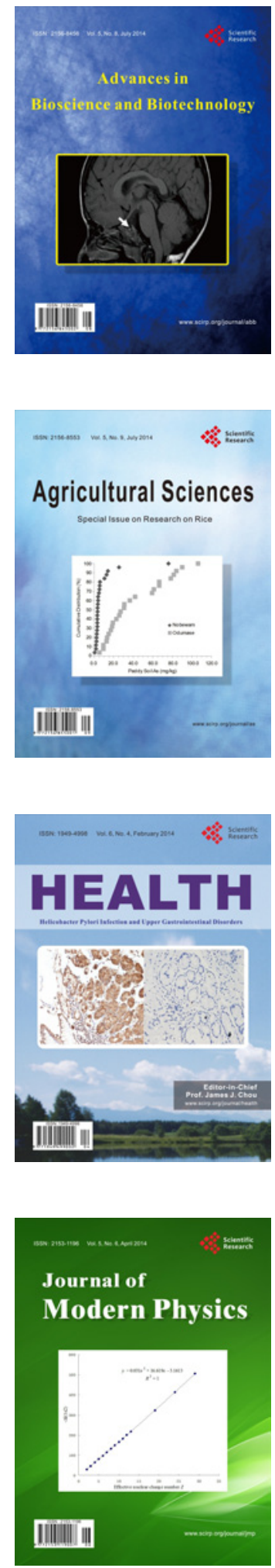
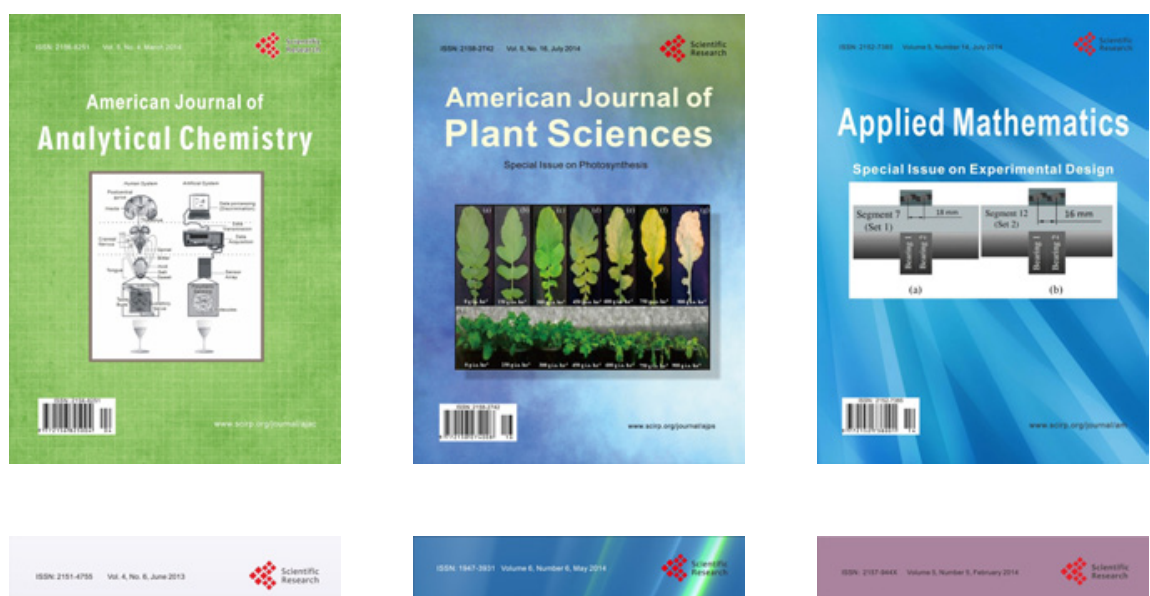

Creative Education
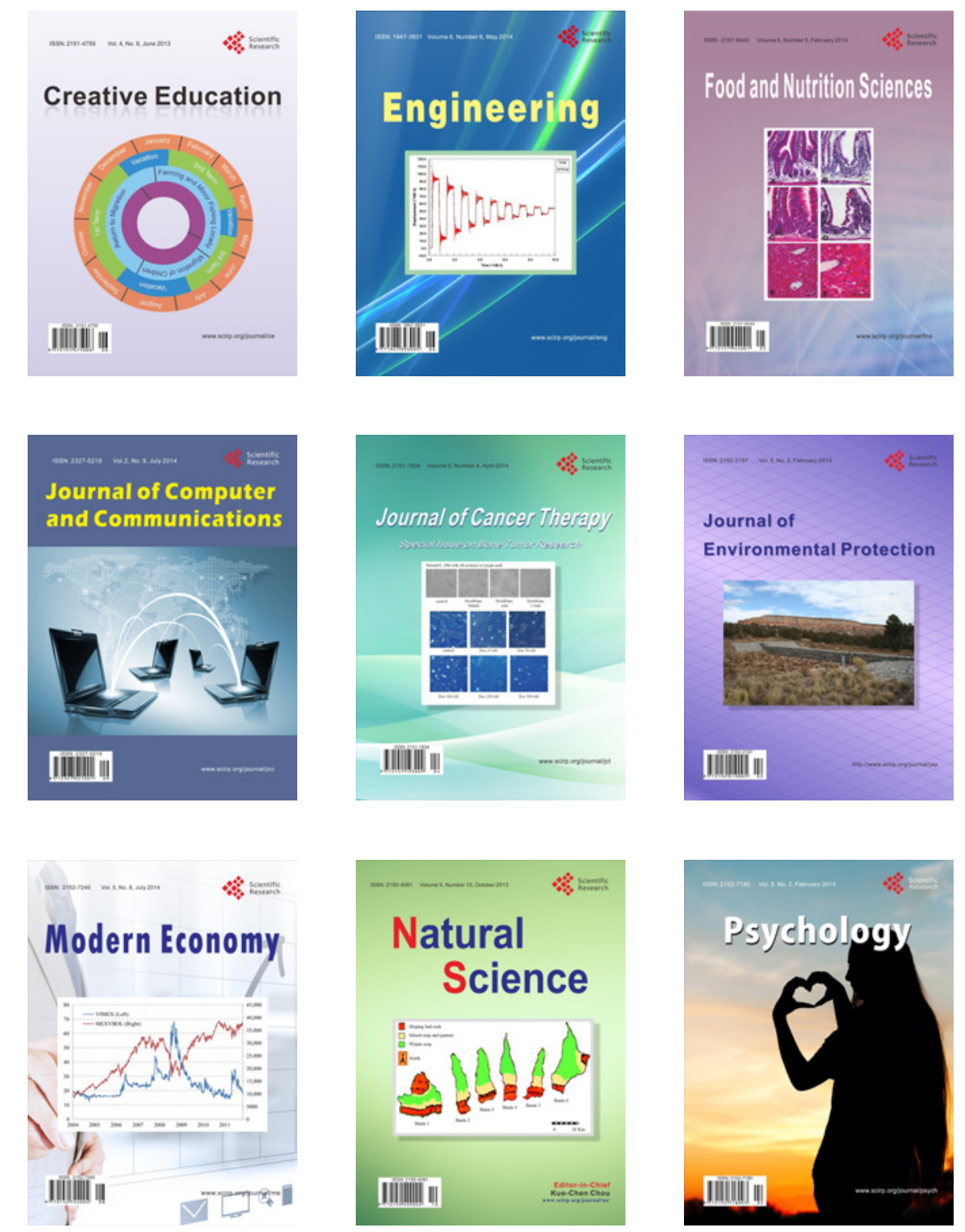